\title{
THE ASSESSMENT OF WATER QUALITY FOR IRRIGATION AND SEDIMENT ALONG ASA RIVER
}

\author{
*Ajala O.N, Olaniyan J.O, Ahamefule H.E, and Affinnih K. \\ Department of Agronomy, Faculty of Agriculture, University of Ilorin, Ilorin Nigeria. \\ ${ }^{*}$ Corresponding Author segnathorg@gmail.com
}

\begin{abstract}
The effects of industrial, agriculture and domestic discharges on the quality of water for irrigation along Asa River located in Ilorin were assessed. In this study, Asa river in which effluent from different industries is discharged was studied for heavy metals ( $\mathrm{Cu}, \mathrm{Pb}, \mathrm{Zn}$ and $\mathrm{Cd}$ ) to ascertain its water quality for irrigation and sediment. Water and sediment samples were collected at four points used for dry season irrigation along the river. The total concentration of $\mathrm{Cu}, \mathrm{Pb}, \mathrm{Zn}$ and $\mathrm{Cd}$ were analyzed using Atomic Absorption Spectrophotometer (AAS) (210/211 VAP model). The range of concentration of these metals in water were $\mathrm{Cu}$ (1.23-5.60) mg/l, Pb (2.20-4.10), Zn (2.60-5.11)mg/l and $\mathrm{Cd}$ (1.80-5.01) mg/l, while that of sediment were $\mathrm{Cu}(1.80-5.09) \mathrm{mg} / \mathrm{kg}, P b(2.54-5.89) \mathrm{mg} / \mathrm{kg}, \mathrm{Zn}$ (3.84-5.21) $\mathrm{mg} / \mathrm{kg}$ and $\mathrm{Cd}(3.02-6.02) \mathrm{mg} / \mathrm{kg}$. It was found that the metals in water and sediment were above the permissible level by FEPA (1999) and W.H.O (1996). The index of salinity hazard in water was found below the FAO (1997) standard for $E C$ (0.04-0.29) and $\mathrm{pH}(6.0-6.3)$ as well as U.S Salinity (1954) level for SP (0.17-0.44)\%, which showed that the water was not saline. Pyrite was prominent at location three receiving effluent from a detergent and pharmaceutical industries ladened Osere river and received by Asa River. The finding showed that the quality of Asa River water for irrigation is very poor due to the high level of heavy metals in water and sediment. Consequently, the high level of metal concentration in the study area would lead to the people dependent on this river water for domestic use including cooking, bathing, washing and even drinking or for agricultural uses like fishing and farming may be exposed to public health risks. Also, the irrigated soil by this River water would influence soil processes and soil organism induction to the soil ecosystem through a reduction in the soil microbial population and the concomitant soil nutrient transformation. Similarly, due to the high level of these metals in the soil which could be transfered to the plant tissue (vegetables), their consumption could be cancerous.
\end{abstract}

Keywords: Asa River, Heavy metals and salinity hazard, water quality and sediment pollution.

\section{INTRODUCTION}

Water is the most important input required for plant growth in agricultural production. Water-needs for plant growth are met with soil water storage in plant root zone. Under rain fed condition soil water is continuously replenished with natural rainfall. However, irrigation is essential to maintain soil 
water storage at an optimum level to get higher yield. It is equally important as supplement for dry season crop production (Arnon, 1997). Monitoring of the river water quality is necessary in the present day society, especially for rivers affected by urban effluents (Amadi et al., 2010). The proportion of water in all living beings and the relevance of water to physiological processes of life affirm that water is life, also water is necessary for domestic uses like drinking, cooking, washing e.t.c. It is use for agricultural purpose includes cropping, flock watering, fish culturing and nursery of seedlings. (Okoro.,et al 2012). Water is an indispensable natural resource, a basic need of living beings and a precious natural asset to human development. Although, over 70 percent of the planet is water however, people have long acted as if these bodies of water could serve as a limitless dumping ground for domestic and industrial wastes (Adekola and Eletta, 2007, Kalwale and Savale, 2012). This attitude has made majority of fresh water bodies undesirable for man's needs. Water is vital to our existence and its importance in our daily life makes it imperative that thorough assessment and physico-chemical determination be conducted on water (Lamikaran, 1999).

Water pollution has become a menace in recent times, causing great damage to the aquatic ecosystems. Waste from industries and domestic uses gradually find their way into the aquatic environment. Most of the water bodies have become polluted due to haphazard and extravagant deposit of wastes into them and making it unfavourable for aquatic organism (Ayoola et al, 2014) River waters are being polluted by indiscriminate disposal of sewerage, industrial waste and plethora of human activities, Of all the human activities, industrial waste is the most common source of water pollution in recent times (Ogedengbe et al., 2004)

The situation has aroused global concern over public health impacts attributed to the deterioration of rivers and soil as a result of pollution (Kimani, 2007; Adekunle and Eniola, 2008) The deterioration of water quality and soil in physical as well as chemical properties is often slow and not readily noticeable as the water system adapts to the changes until an apparent alteration of the water occurs (Zahraa et al., 2012). It becomes imperative to monitor the quality of the river in order to prevent it from further deterioration and ensure availability of quality water for domestic and agricultural purposes (irrigation activities).

River Asa is of strategic importance to the people of llorin. It is located by latitude $8^{0} 26^{1} \mathrm{~N}$ and longitude $4^{0} 30^{1} \mathrm{E}$ with an area of about $100 \mathrm{~km}^{2}$ for water supply to the community and it is also used for irrigation along its course. Asa River supplies the basic water needs of Ilorin city and its environs 
after treatment atAsa Dam treatment plant. The shortage of sufficient potable water has lead many people to depend on this river not only for drinking but also, for other domestic, irrigation and industrial uses. Therefore, its pollution status is thus of serious concerns worthy of investigation and assessment. This study assessed the quality of Asa river water and its sediment for dry season irrigation by determining the level of heavy metals and some physico-chemical parameters.

\section{The Materials and Methods}

\section{The Description of Study Location}

The study area covered selected portions of Asa river and is located at the llorin West Local Government of Kwara State. Asa River is the main river in llorin, it flows in the South-north direction. It divides llorin into two parts: the western part representing the core or indigenous area and the eastern part where the Government Reservation Area (GRA) is located (Oyebanji, 1993).

The river has a major river of economic, agricultural and environmental significance in llorin. Its tributaries in Ilorin are Agba, Aluko, Atikeke, Mitile, Odota, Okun and Osere.

\section{The Study Layout}

Four locations which are used by farmers for dry season irrigation along Asa River bank were selected for the study. The position selected at an interval of $200 \mathrm{~m}$ from each other. The control locations are (0m upstream $\left.08^{0} 27^{1} 05.5^{11} \mathrm{~N}, 004^{0} 35^{1} 33.6^{11} \mathrm{E}\right)$, location ii (200m downstream at $\left.08^{0} 28^{1} 03.1^{11} \mathrm{~N}, 004^{0} 33^{1} 29.7^{11} \mathrm{E}\right)$, location iii $\left(400 \mathrm{~m} 08^{0} 28^{1} 41.8^{11} \mathrm{~N}, 004^{0} 33^{1} 34.4^{11} \mathrm{E}\right)$ and location iv $\left(600 \mathrm{~m} 08^{0} 29^{1} 56.6^{11} \mathrm{~N}, 004^{0} 34^{1} 08.5^{11} \mathrm{E}\right)$ respectively.

\section{The Data Collection}

Water and sediment samples were collected at each farm site plus the control at the upstream, making four (4) water and four (4) sediment samples. These water samples were collected in plastic bottles and $1 \mathrm{~cm}^{3} \mathrm{HNO}_{3}$ was added immediately to keep the metals in solution according to (US Salinity Laboratory Staff, 1954). These water and sediment samples collected were used for the determination of heavy metals. Another water samples were collected in the morning and stored in 
plastic bottles without any acid addition and then taken to the laboratory for the determination of $\mathrm{pH}$, E.C, $\mathrm{Ca}, \mathrm{Mg}$ and SP. The river sediment samples were collected in polythene bags and later air dried in the laboratory.

\section{The Samples' Preparation}

Sediment samples were air-dried in the laboratory and sieved with $2 \mathrm{~mm}$ mesh so as to remove some particles, roots, and stones. In order to finally make quite homogenic samples, $2 \mathrm{~g}$ of the samples sieved were weighed according to (US Salinity Laboratory Staff, 1954) into a digestion flask and treated with $10 \mathrm{ml}$ of acid mixture $\left(\mathrm{HNO}_{3}, \mathrm{HCl}\right.$ and $\left.\mathrm{H}_{2} \mathrm{SO}_{4}\right)$ heated for 30 minutes on an electric hot plate at $80-90^{\circ} \mathrm{C}$ boiled and a clean solution was obtained. After cooling, the solutions were filtered with whatman No. 4 filter paper and then transferred quantitatively to a $100 \mathrm{ml}$ volumetric flask and $50 \mathrm{ml}$ de-ionized water was added (Sobukola et al., 2007). The solutions were then preserved in a universal bottle for heavy metals' analyses. Also $10 \mathrm{ml}$ nitric acid was added to $50 \mathrm{ml}$ water sample and the content was digested till brown fumes of nitric acid had escaped (Agbenin, 1995), for the same analyses.

\section{Laboratory analyses}

The following parameters ( $\mathrm{pH}, \mathrm{E} . \mathrm{C}, \mathrm{Ca}, \mathrm{Ca}+\mathrm{Mg}, \mathrm{Na}$ and $\mathrm{K}$ ) in water were analyzed in the laboratory according to (US Salinity Laboratory Staff, 1954)

\section{Salinity Hazard determination in water}

Sodium percentage (SP) was used as indices of salinity hazard in water (Majumdar, 2004). It was calculated thus;

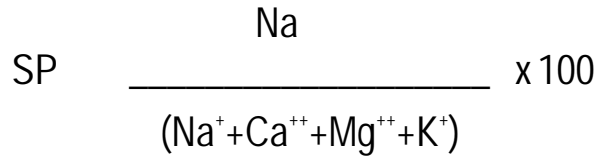

\section{The Results and Discussion}

\section{Heavy metals in water}

The result of heavy metals ( $\mathrm{Cu}, \mathrm{Zn}, \mathrm{Pb}$ and $\mathrm{Cd}$ ) pollution determined in water samples from Asa 
River are shown in table 1. The metal concentrations were higher in all the locations and found to be far above the World Health Organization (WHO) and Federal Environmental Protection Agency (FEPA) recommended level in water. Generally, the sources of these pollutants could be ranged from industrial to agricultural, domestic and anthropogenic occurences.

This finding was also reported by Eletta, (2004) and Adekola and Eletta, (2007). The reason for the decrease in concentration of these heavy metals at location four ( $600 \mathrm{~m}$ downstream) could be probably due to the dilution effect of the river as a result of rainfall and the settling of heavy metals along the sediment. The results of these analyses showed that the concentration of these metals in the water samples were higher than the permissible level given by FEPA and W.H.O, except for Zn concentration which was found to be below the permissible level of W.H.O at the control site, location two $(200 \mathrm{~m})$ and location four $(600 \mathrm{~m})$. The observation that the concentration of $\mathrm{Cu}, \mathrm{Pb}$ and $\mathrm{Cd}$ was higher than the permissible level by FEPA and W.H.O, may be attributed to anthropogenic input which got distributed into the water body and sediment during the course of their transportation. This was also reported by Eletta, (2004). These inputs are vehicle emission, auto workshop, steel and iron industries located between $0 \mathrm{~m}$ distance and $(200 \mathrm{~m})$ while inputs between $200 \mathrm{~m}$ and $400 \mathrm{~m}$ distance were from the activities of coca cola, 7up industries as well as effluents from soap and detergent, pharmaceutical and hospitals effluent discharges into Osere River received by Asa River. It was further revealed that long term use of such river water for irrigation may cause accumulation of toxic metals in soils, which may lead to their elevated levels in plants through bio-accumulation. Consumption of such plants may pose a potential threat to human and animal's health(Bjuhr, 2007).

Table 1: Heavy Metal Contents of Asa River Water

\begin{tabular}{ccccc}
\hline Locations & $\mathrm{Cu}$ & $\mathrm{Pb}$ & $\begin{array}{c}\mathrm{Zn} \\
\mathrm{Mg} / \mathrm{l}\end{array}$ & $\mathrm{Cd}$ \\
\hline $0 \mathrm{~m}$ & 1.23 & 2.20 & 2.60 & 1.80 \\
$200 \mathrm{~m}$ & 2.59 & 3.90 & 4.22 & 3.13 \\
$400 \mathrm{~m}$ & 5.60 & 4.10 & 5.11 & 5.01 \\
$600 \mathrm{~m}$ & 4.25 & 3.76 & 3.82 & 3.62 \\
\hline
\end{tabular}




\section{Heavy Metal Concentration in the Sediment}

Table2 shows the heavy metals' load of the sediments below corresponding river water sample collection points. Generally, the sediments heavy metal concentration increased from location one (control) to location three $(400 \mathrm{~m})$ with a decline in location four $(600 \mathrm{~m})$.

Copper $(\mathrm{Cu})$ concentration in the sediment samples ranged from $1.863-5.094 \mathrm{mg} / \mathrm{kg}$. Lead (pb) concentration in the sediment samples ranged from $2.540-5.890 \mathrm{mg} / \mathrm{kg}$, while Zinc (Zn) concentration in the sediment samples ranged from 3.841-5.217mg/kg, and that of Cadmium (Cd) ranged from $3.081-6.217 \mathrm{mg} / \mathrm{kg}$.

The heavy metals' concentration in the sediment samples was found to be higher than the critical limit stated by FEPA (1999) and WHO (2004), except for Zn concentration which was found to be below the critical limit by W.H.O (2004), but higher than that of FEPA(1999) limit. These metals have been suspected to get into Asa river and sediments as a result of contaminated river water. This is in line with Adekola and Eletta, (2007) who reported that the heavy metals observed in the sediment of Asa river could be attributed to the water that have been contaminated as a result of effluents discharged into the river by industries such as Detergent industries, Dangote flour mill, bottling industries, hospitals, etc. They reported that the concentration of heavy metals, upstream (control) could be from natural and anthropogenic sources. Adekunle and Eniola,(2008) also reported that these metals can be transported by particulate matters to the sediment which serve as the sink for these pollutants. Adekola and Eletta, (2007) purported that heavy metals do not permanently fix in the sediment because they can be released back to column water once there is a change in the physio-chemical conditions. The effects of these metals can lead to various toxic effects on aquatic organisms such as fish and as well as on the health of the humans consuming such animals (Olatunji et al., 2011). Akinyomi et al, (2015) stated that high concentration of heavy metals in the sediments can be harmful to fish and other organisms in the river due to bioaccumulation in the fatty tissues of the organisms, and when consumed by man have fatal effects and seriously affect the ecosystem. Therefore, the high concentration of metals and some of the physic chemical parameters determined in the samples from Asa River may pose a significant threat to aquatic life in the river. Similarly, when this sediment is deposited on the soil as dredged spoil, it can lead to the contamination of such soils with heavy metals. 
Ajala, Olaniyan, Ahamefule \& Affinnih

Table 2: Heavy Metal Contents of Asa River Sediment

\begin{tabular}{ccccc}
\hline Locations & $\mathrm{Cu}$ & $\mathrm{Pb}$ & $\begin{array}{c}\mathrm{Zn} \\
\mathrm{Mg} / \mathrm{kg}\end{array}$ & $\mathrm{Cd}$ \\
\hline $0 \mathrm{~m}$ & 1.86 & 2.54 & 3.84 & 3.02 \\
$200 \mathrm{~m}$ & 3.39 & 5.54 & 4.29 & 4.31 \\
$400 \mathrm{~m}$ & 5.09 & 5.89 & 5.21 & 6.02 \\
$600 \mathrm{~m}$ & 3.91 & 4.78 & 4.01 & 4.02 \\
\hline
\end{tabular}

\section{Some chemical properties of Asa River at selected sampling points}

The result of some chemical properties of Asa River at selected sampling points is shown in Table 3. Chemical properties such as $\mathrm{pH}, \mathrm{EC}$, and Sodium Percentage (Sp) were below permissible level. Generally, the source of these pollutants could range from industrial to agricultural and domestic sources (Adekola and Eletta, 2007).Electrical conductivity (EC) of the water samples for all the locations ranged from $0.04 \mathrm{dsm}^{-1}-0.29 \mathrm{dsm}^{-1}$. The highest value of $0.29 \mathrm{dsm}^{-1}$ was observed at location three $\left(400 \mathrm{~m}\right.$, downstream) while the lowest value of $0.04 \mathrm{dsm}^{-1}$ was observed at location one (control). The results showed that the $\mathrm{EC}$ of the water samples increased as the river flowed downstream. The highest value recorded at farm three $(400 \mathrm{~m}$, downstream) could be attributed to contaminants carried into Asa River from Osere River. Osere River receives the effluents from soap and detergent industry, hospital and pharmaceutical industries (Adekola and Eletta, 2007).

The increase of EC recorded from location two $(200 \mathrm{~m})$ - location four $(600 \mathrm{~m})$ could be the salts added by Coca-Cola, 7Up, as well as the afore listed industries (Eletta, 2004) and it could also be the salts added by laundries, residential and or fertilizer application. The EC of the water samples used for irrigation at all sampled sites was below the critical limits of $0.75 \mathrm{dsm}^{-1}$ as described by FAO (1997). All the water samples in the study showed EC in safe range for irrigation.

The $\mathrm{pH}$ of the water samples ranged from $6.0-6.3$. The highest value of 6.3 was observed at location three $400 \mathrm{~m}$, while the lowest value of 6.0 was observed in location one (control). The results showed that the $\mathrm{pH}$ of the water samples which were slightly acidic increased downstream; the highest value recorded at location three $400 \mathrm{~m}$ which could be as a result of effluents laddened Osere River received by Asa River. The $\mathrm{pH}$ of the water samples used for irrigation at all sampled sites were below the permissible level of irrigation water of $6.5-8.5$ as stated by W.H.O. this indicates that the water samples in the study for $\mathrm{pH}$ were slightly acidic. The implication of this is that 
if the water is continuously used for irrigation, it may affect the microbial activities of the soil, thereby making the soil nutrients (nitrogen, phosphorus, potassium) unavailable to plant. This was also observed by (Bolland et al., 2004)

Sodium percentage (SP) of the water samples ranged from $0.17 \%-0.44 \%$. The highest value of $0.44 \%$ was observed at location three $400 \mathrm{~m}$; while the lowest value of $0.17 \%$ was observed at location one (control site). The results showed that sodium percentage (SP) in the river increased downstream to location three $(400 \mathrm{~m})$ with values more than twice higher compared to control value. This may be due to the inputs from the industries. Though, the results were found below permissible level for irrigation water when compared to the standard of (Bhumbla, 1969) and USSL (1954), who reported that SP should not exceed $60 \%$ for irrigation water. This implies that the water is not hazardous to soil when used for irrigation.

Table 3: Some Chemical Properties of Asa River

\begin{tabular}{cccc}
\hline $\begin{array}{r}\text { Locations } \\
\left(\text { dsm }^{-1}\right)\end{array}$ & EC & pH & SP \\
\hline $0 \mathrm{~m}$ & 0.04 & 6.0 & 0.17 \\
$200 \mathrm{~m}$ & 0.14 & 6.2 & 0.36 \\
$400 \mathrm{~m}$ & 0.29 & 6.3 & 0.44 \\
$600 \mathrm{~m}$ & 0.20 & 6.2 & 0.40 \\
\hline
\end{tabular}

\section{CONCLUSION}

The result from water samples showed that the concentration of heavy metals in water and sediment from all the sampling points exceeded permissible level set by WHO (2004) for water quality and sediment, respectively. The river which unlawfully has become the refuse dumping site for the inhabitants produces foods (fishes, vegetables, tomatoes, etc.) directly or indirectly for the people of the city. Variations in heavy metal concentrations in water and sediment are the consequences of a wide range of human activities; such as soap and detergent industries. Bottling companies and heaps of refuse dumps into the river are the capital sources of pollution. Also, indiscriminate use of fertilizer by the river side farmers facilitate pollution. Proper treatment is imperative for the river to be appropriate for potable, domestic and irrigation purposes. 


\section{RECOMMENDATION}

The Kwara state government is advised to organize a health team which would monitor and ensure that industrial effluents from industries concerned are seriously pre-disinfected, tested and certified. It is also recommended that dumping of refuse along the river channel should be forcefully discouraged.

\section{REFERENCES}

Adekola, F.A. and Eletta, O.A.A. (2007). A Study of Heavy Metal Pollution of Asa River, llorin, Nigeria:trace metal monitoring and geochemistry. Environmental Monitoring and Assessment.125:157 163.

Adekunle, A.S. and Eniola, I.T.K. (2008). Industrial Effluents on Quality of Segment of Asa River Within an Industrial Estate in llorin, Nigeria. New Yorkjournal of science. 1:17-21

Agbenin, J.O (1995). Laboratory Mannual on Soil and Plant Analysis, Guidelines and Criteria forWater Quality Management in Ontario, Ministry of the Environment Toronto, Canada.3436pp.

Akinyomi, A., Babajide, A.I. and Okoro, H.K. (2015).Environmental Studies of Thermal Power Station Effluents.Ethiopian journal of Environmental studies and management 8(3):283-289.

Amadi, A.N., Olashinde, P.I., Okosun, E.A., Yisa, J. (2010). Assessment of the Water Quality Index of Otamiri and Oramiriukwa Rivers.Physics International1(2) 116-123.

Arnon, J. (1997). Crop production in Dry Regions. V.I. Background and principle, London Leonard Hill, 54-56pp

Ayoola, S.O., Adejumobi, K.O. and Adamson, O.H. (2014) Haematological Indices and Enzymatic Biomaker of Black Jaw Tilapia From Lagos Lagoon Agrosearch Journal14(1) 62-75

Bhumbla, M.B. (1969). Toxic Metals in Sewage Sludge-amended Soils: Has proportion of Beneficial use discounted the risks. Adv. Environ. Res., 8: 5-19

Bjuhr J. (2007). Trace Metals in Soils Irrigated with waste water in a Periurba Area Downstream Hanoi City, Vietnam, Seminar Paper, Institution for markvetenskap, Sveriges lantbruks university (SLU), Uppsala, Sweden.936-939pp.

Bolland, M., Gazey, C., Miller, A., Gartner, D. and Roche, J. (2004).Surface Acidity Department of Agriculture and food, Western Australia Bulletin 4602pp.

Eletta, O. A. A. (2004). Physico-chemical Characterization Speciation and Interaction Studies of Some Pollutants in the Water and Sediment of Asa River llorin Nigeria PhD Thesis University of llorin, llorin Nigeria.238pp

FAO. (1997). Soil Bulletin 55, Guidelines: land Evaluation for Irrigated Agriculture Agriculture Organization of the United Nation, Roma, Italy. 
Federal Environmental Protection Agency (1999).Guidelines and Standards for Environment Notice, Federal Republic of Nigeria.

Kalwale, A.M. and Savale, P.A. (2012).Determination of Physico-Chemical Parameters of Deoli Bhorus Dam Water.Advanced Applied Science Research, 3 (1): 273-279.

Kimani, N.G. (2007). Environmental Pollution and Impacts on Public Health: United Nations Environment Programme.1-31pp.

Lamikaran, A. (1999). Essential Microbiology for Students and Practitioners of Pharmacy, Medicine and Microbiology. $2^{\text {nd }}$ Edn.Amkra books. 406pp

Majumdar, D.K. (2004). Irrigation Water Management Principles and Practice.372-373pp

Ogedengbe, K. and Akinbile, C.O. (2004).Nigeria Journal of Technological Development, 4(2) 139-144.

Okoro, H.K., Fatoki, O.S., Adekola, F.A., Ximba,B.J. and Synman, R.G. (2012). A Review of Sequential Extraction and instrumental Techniques for heavy metals speciation in soil and sediment materials, open access scientific Report. 1(3): 181-189, DOI: 10.4172/scientific reports.181.

Oyebanji, J.O. (1993). A Spatio-Temporal Analysis of Activity Linkages in Ilorin, Kwara State. Savannah, Volume 21.24-26

Sobukola,O.P., Adeniran, O.M., Odedairo, A.A., Kajihausa, O.E. (2007). Heavy metals Levels of Some Fruits and Leafy Vegetable From Selected Markets in Lagos, Nigeria. Afri. Food Sci4(2):389-393.

US Salinity Laboratory Staff (1954).Diagnosis and improvement of saline and alkali soils.Agric Handbook No 60, USDA, US Government Printing Office, Washington.166-167pp.

WHO (World Health Organization) Guidelines for Drinking water quality (2004). $3^{\text {rd }}$ Ed., World Health Organization, ISBN:92-4-154638-7. 516pp

Zahraa, Z.A., A. Abdul-Rahman, M.J., Abdul-Hameed, (2012).Journal of Al-Nahrain University, 15(1) $119-126$ 